\title{
Black Central American
}

National Cancer Institute

\section{Source}

National Cancer Institute. Black Central American. NCI Thesaurus. Code C128991.

Denotes a person of African ancestral origins whose family settled in Central America. 